\title{
Judicial Conciliation: Conditions for Effective Development
}

\author{
Ekaterina Ivanova*, Galina Sheremetova, and Elizaveta Solomeina \\ Ural State Law University, Komsomolskaya str. 21, Yekaterinburg, Russia
}

\begin{abstract}
The article examines the problems of effective improvement of a new conciliation procedure in the Russian litigation-judicial reconciliation. The study was carried out based on the results obtained during legal experiments on the integration conciliation procedures into civil proceedings, which took place in the Sverdlovsk region in 2011 - 2014 and in the Lipetsk region - in 2013 - 2014. The study analysed the possibility of attributing judicial conciliation to the models of conciliation procedures (private or integrated). Authors concluded that it is impossible to classify judicial conciliation as only one certain model due to the presence of features from both private and integrated models of conciliation procedures. The authors carried out comparative analysis between the judicial conciliation and mediation. Overall, the conclusion is the following - the requirements for a mediator and for a judicial conciliation should be identical in terms of qualifications. In order to obtain qualifications, a judicial conciliator must undergo special training. The implementation of the set out conclusions on the need for special training of judicial conciliators will lead to an increase in the effectiveness of the application of the judicial conciliation procedure and, as a consequence, to a caseload decrease.
\end{abstract}

\section{Introduction}

Amendments to the Civil Procedure Code, Commercial Procedure Code, as well as the Administrative Procedure Code that were made by the Federal Law of July 26, 2019 No. 197-FZ "On Amendments to Certain Legislative Acts of the Russian Federation" were analyzed in many ways by researchers in last few years $[1,2]$. However, these innovations were a new step in the development of conciliation procedures. The legislator added judicial conciliation to the previously established conciliation procedures such as negotiations, conciliation, including mediation.

The initiator of the amendments was the Supreme Court of the Russian Federation. The Explanatory Note to the draft of the Federal Law "On Amendments to Certain Legislative Acts of the Russian Federation in Connection with the Improvement of Conciliation Procedures" says that in Russian society there is a high need for affordable and effective dispute settlement mechanisms. It has to not only improve the quality of justice by optimizing the judicial burden, but also reduce conflicts, strengthen social and business ties, establish and develop partnerships, foster a respectful attitude towards the law, as well as raise legal awareness and social activity [3].

Thus, judicial conciliation ought to become another conciliatory procedure, allowing one, on the one hand, to harmonize society, and on the other hand, to reduce the judicial burden.

The procedure for judicial conciliation is regulated not only by procedural legislation, but also by the Regulations for the Conduct of Judicial Conciliation, approved by Resolution of the Plenum of the Supreme Court of the Russian Federation of October 31, 2019 "On approval of the Regulations for the conduct of judicial conciliation" $\mathrm{N} 41$. This act defines the goals and the objectives of judicial conciliation, its principles, requirements for a personality of the judicial conciliator, rights and obligations of subjects of judicial conciliation, terms and stages of the procedure, grounds and rules for completing the procedure.

According to the Regulations, a judicial conciliator is a retired judge included in the list of judicial conciliators approved by the Plenum of the Supreme Court of the Russian Federation. When forming the list, the following aspects are taken into account: experience as a judge, experience in scientific activity, areas of practice, region of residence, activities carried out by a retired judge from the moment of retirement, and the compliance of this activity with the legislation on the status of judges and the code of judicial ethics.

There are leading scientific studies, illustrating the conciliation procedures, including judicial conciliation $[4,5,6]$. In these works, authors analyze the issues of integrating conciliation procedures into civil proceedings in Russia. However, it cannot be assumed that the model of judicial conciliation implemented in procedural legislation fully fits the models of conciliation procedures (including mediation) described in the listed works. These researchers tend to differentiate private and integrated models of conciliation procedures, while judicial conciliation cannot be fully attributed to any of them. Judicial conciliation contains features of both an integrated and a private model of conciliation procedures. 
Earlier, the legislator, judiciary and scientific researchers actively developed and adopted a private model of conciliation that made it possible to resolve practical problems, which arose at the stage of establishment of these institutions. Judicial reconciliation has not yet become widespread, while the legal basis laid down by the legislator does not yet guarantee its successful practical implementation. In this regard, it seems that the factors affecting the effectiveness of judicial conciliation require a separate study.

Within the framework of this work, due to its limited scope, the purpose of the study is to evaluate the requirements stated by law for a judicial conciliator as a subject conducting judicial conciliation. We assume that one's qualification is one of the factors affecting the effectiveness of the procedure. At the same time, it is important to note the need for the judicial conciliator to have not only knowledge about the procedure and principles of conducting the judicial conciliation procedure, but also knowledge, skills and abilities to use special techniques for conducting conciliation.

\section{Methodology}

An empirical basis for the study consists of the materials and results of two legal experiments: 1) an experiment conducted on the territory of the Sverdlovsk region from 2011 to 2014, 2) an experiment organized on the territory of the Lipetsk region in the period from 2013 to 2014. Both legal experiments took place at a time when mediation as a conciliation procedure, in fact, was at the initial stages of its development in Russia that is quite similar to the current situation in the field of judicial conciliation.

The main purpose of these experiments was to find an optimal model for matching up the conciliation procedure (mediation) and civil proceedings. During the experiment, conducted on the territory of the Sverdlovsk Region, the training of judges was carried out: introductory (the basics of mediation) and in-depth (mediation techniques).

As part of the experiment. In the Lipetsk region, along with the training of judges, an additional education program aimed at the formation of a corps of professional mediators was created. The results of these experiments made it possible to reveal the correlation between the results of the law enforcement activities of the representatives of the judicial community and the mediation activities of professional mediators with their special knowledge, skills and abilities in the field of conciliation procedures.

\section{Results and Discussion}

Judicial conciliation is an independent type of conciliation procedures that includes features of integrated and private models of conciliation procedures. Traditionally, the source of legal regulation is a main feature that distinguishes these models from each other. For a private model, it is typical that regulation is carried out by special laws, for example, Federal Law of July
27, 2010 No. 193-FZ "On an alternative procedure for resolving disputes with the participation of a mediator (mediation procedure)" (hereinafter referred to as the Law on mediation), which regulates the mediation procedure. In an integrated model, no special regulation is required; sectoral legislation is sufficient. As has been noted above, the regulation of judicial conciliation is conducted by sectoral procedural codes, as well as the Regulations for the Conduct of Judicial Conciliation. This act cannot be considered as a special legal act, since the subject approving it is the Plenum of the Supreme Court of the Russian Federation that is a structural part of the Supreme Court and, first, is called upon to ensure the jurisprudence constant by adopting acts of law interpretation.

In Russia, there are no examples of formalized in legislation integrated model of conciliation procedures, while an example of a private model is the mediation procedure. Judicial conciliation as a type of conciliation procedure differs from mediation not only in terms of the source of legal regulation, but also on other grounds. On the one hand, if the mediation procedure begins with the conclusion by the parties and the mediator (or the organization providing mediation) of an agreement to mediate, then the judicial conciliation begins from the moment the court makes a ruling on the conduct of the judicial conciliation.

The court approves the court conciliator, while the parties choose the mediator by themselves. A judicial conciliator may familiarize herself with the case materials with the court consent that makes her very similar to the subjects of the relevant procedural legal relations, but a mediator cannot. Nevertheless, it does not raise any other procedural rights or obligations to a judicial conciliator. The salary of a judge performing the functions of a judicial conciliator is carried out based on the decision of a judge ruling the case at the expense of the funds provided by the federal budget for these purposes to the federal courts, while the parties make the payment for the mediator.

On the other hand, regarding the principles, procedure and the techniques used by the conciliator, the procedure for judicial conciliation is close to the mediation procedure. Thus, the principles underlying the mediation procedure in accordance with the Law on mediation are voluntariness, confidentiality, cooperation and equality of the parties, impartiality and independence of the mediator. In turn, the principles of judicial conciliation in accordance with the Regulations are voluntariness, cooperation, equality of the parties, independence and impartiality of the judicial conciliator, confidentiality, good faith.

The procedure for conducting judicial conciliation, described in the Regulation, practically copies the classical model of mediation that is implemented in many countries $[7,8,9]$. Within the framework of the judicial conciliation, the following stages are distinguished: opening of judicial conciliation (opening statement); statement of the circumstances of the dispute and determination of the interests of the parties; creating the list of questions for discussion. This also includes individual conversation of the judicial conciliator with 
the parties and their lawyers; working out of proposals for the settlement of the dispute; registration of the results of conciliation, including the conclusion of a settlement agreement, a conciliation agreement, an agreement on facts and circumstances, dropping a claim, pleading no defense; or completion of judicial conciliation.

Thus, it is possible to conclude that the content of the judicial conciliation procedure and the mediation procedure is very similar. Therefore, the subjects carrying out these procedures must have the same qualification. At the same time, since the object of the judicial conciliation procedure is the dispute submitted to the court, it is possible to talk about the same requirements for the qualifications of judicial conciliator with a professional mediator. These requirements are stated in the Article 16 of the Law on mediation as a necessity to receive additional professional education in the area of mediation. So, retired judges who can be professional mediators must also comply with this requirement.

Additional professional education on mediation allows the mediator to obtain and implement the following competencies: communication, conflict analysis, negotiation and procedural competence. The mediator's skill of these competencies allows her to successfully assist the parties in resolving the conflict, consciously lead them to the expected result from the mediation procedure.

As the practice of conducting legal experiments has shown, the conscious using of knowledge and mastery of the techniques of conciliation procedures contributes to:

- Effective implementation by the judge of the goal on the stage of preparing the case for trial - facilitating the conciliation of the parties;

- The effective conduct of the mediation procedure.

In the first year of the experiment in the Sverdlovsk Region, a small number of judges underwent introductory training, but the number of applications for mediation at the Center for Mediation of the Ural State Law University (as the only organization providing mediation within the framework of this experiment) has almost doubled compared to the year preceding the experiment.

The second year of the experiment was marked by the expansion of the number of its participants: more than one hundred judges were trained in the methodology of explaining the right to mediation. In the second year, the increase in requests for mediation after the explanation of this right by a trained judge was 290 percent compared to the first year of the experiment. In the third year of the experiment, the growth of such calls was 140 percent compared to the previous year [10].

Researchers realized the experiment in the Lipetsk region taking into account the achievements of the experiment carried out on the territory of the Sverdlovsk region. In particular, the conclusion that the qualitative explanation of the right to conciliation on the part of the court is necessary for the effective application of the mediation procedure, underlie the demand of familiarizing judges with the basics of this procedure and training in the methodology for explaining this right. For this, several groups of judges receive appropriate training. In addition, for the successful implementation of the project, it was necessary to form a corps of professional mediators who would ensure the conduct of conciliation procedures, for which training was conducted under the new advanced training program.

As a result, initially in the year preceding the experiment, the number of applications to mediators in the region was 153 and only $40 \%$ of the dispute was settled based on the results of mediation, then during the experiment the number of calls increased to 709 (in 2013) and 707 (in 2014). At the same time, the percentage of successful settlement of the dispute varied from 83 percent in 2013 to 92 percent in 2014 [11].

Despite the end of the experiment, the courts and professional mediators of the Lipetsk region keep actively applying the knowledge, skills and abilities acquired during the experiment, as evidenced by the following results (Table 1).

Table 1. Results of the experiment.

\begin{tabular}{|c|c|c|}
\hline Year & $\begin{array}{c}\text { Number of } \\
\text { mediations }\end{array}$ & $\begin{array}{c}\text { Percentage of successful } \\
\text { completion of mediation }\end{array}$ \\
\hline 2015 & 294 & 94 \\
\hline 2016 & 464 & 97 \\
\hline 2017 & 477 & 97 \\
\hline 2018 & 555 & 93 \\
\hline 2019 & 493 & 96 \\
\hline
\end{tabular}

Indirectly, the results of in-depth training of judges of the Sverdlovsk region testify to the effectiveness of the application of special knowledge of the techniques of conciliation procedures. Thus, because trained judges practice these techniques in their professional activities, on average, the number of cases in which the judge dismiss a matter doubled (to the total number of cases completed) (Table 2).

Table 2. Percentage of dismissed matters to the total number of cases [4].

\begin{tabular}{|l|c|c|}
\hline Judge & $\begin{array}{c}\text { A year before the } \\
\text { education }\end{array}$ & $\begin{array}{c}\text { A year after the } \\
\text { education }\end{array}$ \\
\hline Judge 1 & 5.02 & 10.25 \\
\hline Judge 2 & 5.93 & 12.08 \\
\hline Judge 3 & 7.48 & 11.54 \\
\hline $\begin{array}{l}\text { Average for the } \\
\text { court }\end{array}$ & 7.3 & 5.63 \\
\hline
\end{tabular}

Therefore, the achieved results of legal experiments allow researchers to conclude that the training of judges contributes not only to the effective implementation of the goal of the stage of preparing the case for trial - to facilitate the reconciliation of the parties, but also ensures the achievement of such a goal of legal 
proceedings as a peaceful settlement of disputes. It usually take place in a number of cases when a judge uses mediation techniques. At the same time, it can be concluded that the most effective mediation procedure shows itself in a situation when both subjects - the judge and the mediator - have special knowledge about this procedure.

The statistics of civil and administrative cases in courts of general jurisdiction in the first instance in 2020 shows the following efficiency of the application of conciliation procedures [12] (Table 3).

Table 3. Statistics of civil and administrative cases.

\begin{tabular}{|c|c|c|c|}
\hline 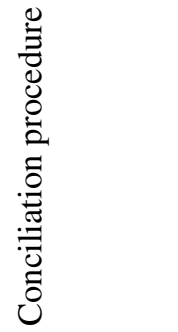 & 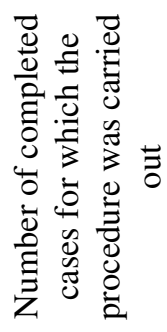 & 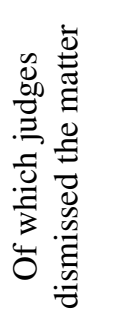 & 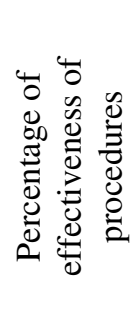 \\
\hline Mediation & 1433 & 560 & 39 \\
\hline $\begin{array}{l}\text { Judicial } \\
\text { conciliation }\end{array}$ & 747 & 212 & 28 \\
\hline
\end{tabular}

In this case, the mediation procedure has shown great efficiency from the point of view of the parties settling the dispute without a court decision. At the same time, since it is used statistical data for the Russian Federation, researchers assume that the judges who explained to the parties the right to apply to the mediation to resolve the dispute did not undergo special training. Thus, mediators who carried out the procedure in cases submitted to the court underwent such training, since professional mediators have to follow this requirement according to the Law on Mediation.

The situation is different with regard to judicial conciliation. There are no requirements for training for judicial conciliators. In other words, both subjects - the judge who sends them to the judicial conciliation procedure and the judicial conciliator who carries out the procedure - do not have special skills set in the conciliation procedure.

Hence, the judicial conciliation will be most effective when both the judge and the judicial conciliator have special knowledge in the area of conciliation procedures. For the judge, this knowledge is important and should be used to explain to the parties their right to apply for conciliation procedures to resolve the dispute. The judicial representative practices them during the judicial conciliation procedure, reconciling the interests of the parties.

\section{Conclusion}

As one of the types of conciliation procedures, judicial conciliation combines the features of integrated and private models of conciliation procedures, representing a complex model of conciliation procedures. At the same time, procedurally and substantively, judicial conciliation is carried out in the same way as mediation. In this regard, it seems reasonable that the requirements for the subjects conducting both the mediation procedure and the judicial conciliation procedure, specifically the request of special knowledge on the procedural rules for conciliation and the used techniques, are more than justified as demonstrated in the results of legal experiments.

It should also be noted that it is inadmissible to ignore the results of legal experiments demonstrating the success of the procedure in cases where the judge hearing the case also has knowledge of the essence of the procedure and the techniques used.

Such knowledge allows, firstly, to more skilfully identify disputes, for the settlement of which the use of conciliation procedures will be most effective and, secondly, to determine the most appropriate conciliation procedure. It seems that in the future, the experience of the Center for Mediation of the Ural State Law University can be taken as a basis for the creating of requirements for judicial conciliators.

Moreover, these types of legal schools and scholars that regularly conduct research and analyse practice have lots of experience to produce training programs for judges of the Russian Federation (for example, "Mediation techniques in judicial activity", developed and implemented by the Center during experiments).

\section{References}

1. E. Alekseevskaya, Russian Law Journal, 8(2), 120143 (2020). DOI: https://doi.org/10.17589/23098678-2020-8-2-120-143.

2. O. Pankova, Y. Migachev, BRICS Law Journal, 7(1), 119-147 (2020). DOI: https://doi.org/10.21684/2412-2343-2020-7-1-119147.

3. Legislative support system of the State Automated System "Lawmaking". Retrieved from: https://sozd.duma.gov.ru/bill/421600-7

4. S.K. Zagaynova, Herald of Civil Procedure, 6, 2637 (2012)

5. V.O. Abolonin, Judicial Mediation: Theory, Practice, Perspectives (Infotropic Media, Moscow, 2014)

6. S.I. Kalashnikova, Mediation in the Field of Civil Jurisdiction (Infotropic Media, Moscow, 2011)

7. F. Ferrari, Russian Law Journal, 2(3), 80-95 (2014). DOI: https://doi.org/10.17589/2309-8678-2014-2-380-95.

8. T.A. Wambier, C.S., BRICS Law Journal, 3(4), 640 (2016). DOI: https://doi.org/10.21684/24122343-2016-3-4-6-40.

9. G. Nan, Bulletin of the St. Petersburg State University. Law, 11(1), 192-206 (2020). DOI: https://doi.org/10.21638/spbu14.2020.114. 
10. G.S. Sheremetova, Russian Yearbook of Civil and Commercial Process, 10-11, 501-507 (2012-2013)

11. Official website of the Lipetsk Regional Court. Retrieved from: http://oblsud.lpk.sudrf.ru/modules.php?name=docu m_sud\&id=2540.
12. Official website of the Judicial Department at the Supreme Court of the Russian Federation. Retrieved from:

http://www.cdep.ru/index.php?id=79\&item=5671 